\title{
Fintech and Banking: Evidence from Vietnam
}

\author{
Nguyen Thi Kim LIEN ${ }^{1}$,Thu-Trang Thi DOAN² , Toan Ngoc BUI ${ }^{3}$
}

Received: July 01, 2020 Revised: July 19, 2020 Accepted: August 10, 2020

\begin{abstract}
The paper focuses on understanding fintech and the application of fintech in the banking sector in Vietnam. To solve this research objective, the authors analyze fintech development trends, especially the fintech application in the banking sector in Vietnam. To improve the quality of fintech services at banks, the authors conducted consideration of factors affecting customers' intention to use fintech services. To accomplish this, the authors collected data through a survey of 620 customers of the banks located in Ho Chi Minh City - the largest economic center in Vietnam. For the analytical method, the authors used multivariate regression to estimate the research model. Research results show that fintech service is very important for the banking sector in Vietnam. Moreover, this paper has achieved great success by identifying the factors that influence customers' intention to use fintech services. Accordingly, the intention to use fintech (INT) services is positively affected by the perception of usefulness (PU), social impact (SI), customer trust (TRU), and perceived ease of use (PEU). Based on the results of this study, bank managers will have a basis to improve the quality of fintech services. Not only that, the results of this study are also valuable for policymakers and researchers.
\end{abstract}

Keywords: Banking, Financial Technology, Fintech, Intention, Vietnam

JEL Classification Code: G00, G21, O16

\section{Introduction}

Financial technology (fintech) is a combination of "finance" and "technology" (Hu, Ding, Li, Chen, \& Yang, 2019; Thakor, 2020). Therefore, fintech is the term used to describe the use of technology in financial services (Nguyen, 2020; Nguyen, Dinh, \& Nguyen, 2020; Thakor, 2020). In other words, fintech can be understood as the application of technological innovations to provide financial services (Gomber, Koch, \& Siering, 2017). These services may be

${ }^{1}$ First Author. Faculty of Finance and Banking, Industrial University of Ho Chi Minh City (IUH), Vietnam.

Email: nguyenthikimlien@iuh.edu.vn

${ }^{2}$ Corresponding Author. Faculty of Finance and Banking, Industrial University of Ho Chi Minh City (IUH), Vietnam [Postal Address: No. 12, Nguyen Van Bao Street, Ward 4, Go Vap District, Ho Chi Minh City, 700000, Vietnam] Email: doanthithutrang@iuh.edu.vn ${ }^{3}$ Faculty of Finance and Banking, Industrial University of Ho Chi Minh City (IUH), Vietnam. Email: buingoctoan@iuh.edu.vn

(c) Copyright: The Author(s)

This is an Open Access article distributed under the terms of the Creative Commons Attribution Non-Commercial License (https://creativecommons.org/licenses/by-nc/4.0/) which permits unrestricted non-commercial use, distribution, and reproduction in any medium, provided the original work is properly cited. formed based on new innovative ideas, or maybe outdated but provided in a new way with the purpose to simplify transaction procedures and help to improve access to financial services of customers (Gomber et al., 2017; Milian, Spinola, \& Carvalho, 2019; Phan, Nguyen, \& Bui, 2019). Therefore, fintech plays a significant role in the development of the banking industry. Indeed, fintech has gradually broken the traditional banking model, giving customers more options when accessing banking services with the lowest cost (Berger, 2003). Since its first appearance in 1950, fintech has gained worldwide attention.

Today, fintech has been widely applied in many countries, especially in countries with good background in economics and information technology such as China, Korea, India, Finland and the United Kingdom (Kim, Choi, Park, \& Yeon, 2016). However, in developing countries like Vietnam, fintech is still quite new and promises to have breakthrough developments in the future. In Vietnam, fintech has received much attention from policy makers, researchers, and especially regulators in the banking industry. Fintech is also the subject of much discussion in forums and conferences. However, virtually no empirical research has been conducted to learn about fintech and fintech applications in the banking sector in Vietnam. 
Therefore, this is an interesting research topic and there is still a lot of room to explore in Vietnam. Recognizing this, the authors will conduct this study to learn about fintech and fintech application in the banking sector in Vietnam. In particular, the authors also consider the factors that influence customers' intention to use fintech services. With research data collected through the survey process from bank customers. The research results are expected to be important for policymakers, researchers, and regulators in the banking industry.

\section{Literature Review and Hypothesis Development}

By using fintech, banks will expand the scope of service provision to customers (Philippon, 2015; Nakashima, 2018). Therefore, fintech is not a simple combination of information technology and financial services, but a technology application for traditional services to expand the scope (Arner, Barberis, \& Buckley, 2015). For customers, fintech creates many new experience opportunities and helps customers more convenient to transact (Devadevan, 2013). Indeed, fintech can help customers experience banking services on mobile devices, such as mobile phones and tablets. Therefore, customers can use banking services everywhere, instead of having to go to the traditional counter (Kim et al., 2016). Therefore, it can be said that fintech services play a very important role in the banking sector (Kim et al., 2016; Fuster, Plosser, Schnabl, \& Vickery, 2019), and at the same time bring many customer benefits (Salmony, 2014; Chen, Wu, \& Yang, 2019). To improve the quality of fintech services in the banking sector, it is important to consider factors that affect customers' intention to use fintech services. Because, when increasing the intention to use fintech services of customers, banks will expand market share and improve operational efficiency. For the intention of the customer, this can be interpreted as the readiness of the service in the future. Intent can explain $70 \%$ of actual customer service behavior (Venkatesh, Morris, Davis, \& Davis, 2003). Regarding factors affecting customers' intention to use fintech services, focusing on four factors: Perceived usefulness (PU), perceived ease of use (PEU), customer trust (TRU), and social influence (SI).

\subsection{Perceived Usefulness (PU) and Intention to Use Fintech (INT) Services}

The usefulness of the service can significantly impact the customer's intention to use fintech services. Because the service is highly useful, it will improve the service quality, while improving the efficiency of the user. Moreover, fintech service can provide a more interesting experience for customers, thereby overcoming the limitations of traditional banking services. So, it can be said that the perception of usefulness can positively impact customers' intention to use fintech services (Ryu, 2018). This effect is also found in many empirical studies, such as Kim et al. (2016), Lee (2017), Wonglimpiyarat (2017), Tran, Han, and Yun (2018). Based on this basis, the authors propose the following research hypotheses:

$\boldsymbol{H}_{I}:$ Perception of usefulness (PU) has a positive impact on the intention to use fintech (INT) services.

\subsection{Perceived Ease of Use (PEU) and Intention to Use Fintech (INT) Services}

The perception of ease of use can be understood as the degree to which users feel comfortable and easy to use fintech services. Fintech service, if used easily, can provide interesting experiences for customers, thereby meeting the individual needs of each customer. If the use of fintech services is difficult, customers will be very likely to encounter errors when using, this can cause financial losses for customers. Therefore, the feeling of ease of use is one of the core factors that lead to customers' intention to use services (Chau \& Ngai, 2010; Abbad, 2013). In other words, the perceived ease of use can positively impact the customer's intent to use fintech services. This effect is also found in empirical studies of Riquelme and Rios (2010), Akturan and Tezcan (2012), Szopinski (2016). So, the research hypothesis proposed by the authors is as follows:

$\boldsymbol{H}_{2}$ : The perception of ease of use (PEU) has a positive impact on the intention to use fintech (INT) services.

\subsection{The Trust of Customers (TRU) and Intention to Use Fintech (INT) Services}

Trust is always one of the important factors to attract customers intending to use fintech services (Hu et al., 2019). Indeed, Kesharwani and Bisht (2012) suggest that user trust can have a significant impact on their behavior. In another study, Hanafizadeh, Behboudi, Koshksaray, and Tabar (2014) also found the impact of trust on customers' intention to use fintech services. Therefore, the authors propose the following research hypotheses:

$\boldsymbol{H}_{3}$ : Customer trust (TRU) has a positive impact on the intention to use fintech (INT) services.

\subsection{Social Influence (SI) and Intention to Use Fintech (INT) Services}

Social influence can be understood as the extent to which customers find that people who are important to them in 
society (such as relatives, friends, colleagues) trust using the services. When customers see that people in society use fintech services, they tend to use it (Koksal, 2016). Therefore, social influence can be an important factor and have a positive impact on customers' intention to use services (Abrahão, Moriguchi, \& Andrade, 2016; Kissi, Oluwatobiloba, \& Berko, 2017; Isaac, Abdullah, Aldholay, \& Ameen, 2019). This effect is also found in many empirical studies, such as Kim et al. (2016), Oliveira, Thomas, Baptista, and Campos (2016). Based on this basis, the research hypothesis proposed by the authors is as follows:

$\boldsymbol{H}_{4}$ : Social influence (SI) has a positive impact on the intention to use fintech (INT) services.

\section{Methodology}

The paper focuses on understanding fintech and the application of fintech in the banking sector in Vietnam. To solve this research objective, the authors analyze fintech development trends, especially the fintech application in the banking sector in Vietnam. To improve the quality of fintech services at banks, the authors conducted consideration of factors affecting customers' intention to use fintech services. To accomplish this, the authors collected data through a survey of 620 customers of banks in Ho Chi Minh City, which is the largest economic center of Vietnam. The survey period is from October 2019 to December 2019 according to the pre-designed survey questionnaire.

For the analytical method, the authors used multivariate regression to estimate the research model. Before conducting regression analysis, the authors conducted Cronbach's Alpha test and exploratory factor analysis (EFA) to determine the appropriate factors to put into the research model.

The research model is built based on the results of previous studies and the research hypotheses that the authors have proposed. Accordingly, the dependent variable is the intention to use fintech (INT) service. Independent variables includeperception of usefulness (PU), perceived ease of use (PEU), user trust (TRU), and social impact (SI).

\section{Empirical Results}

\subsection{Fintech Development Trend in Vietnam}

In the recent years, the startup trend has spread everywhere in Vietnam. More and more startups have been established, especially in fintech area. Vietnam had about 40 fintech companies in 2016 and reached more than 150 companies by the end of June 2019. In Vietnam, although fintech is still quite new, the number of fintech companies is increasing quickly. In particular, most fintech companies are providing customers with online payment tools (such as Onepay, 123 Pay, Vina Pay or MoMo). Also, some fintech companies are providing the services of money transfer (such as Matchmove, Cash2vn or Remittance Hub), mobilizing community capital (such as FundStart or Comiloca), and online lending (such as LoanVi or Tima). With the growing trend of fintech development, Vietnam has attracted many foreign investors in this field. For example, in early 2018, Lotte Card (belonging to Lotte Group of Korea) spent nearly VND 1,700 billion to acquire Techcom Finance from Vietnam Techcombank. Currently, this company (Lotte Finance) is providing consumer lending services in Vietnam.

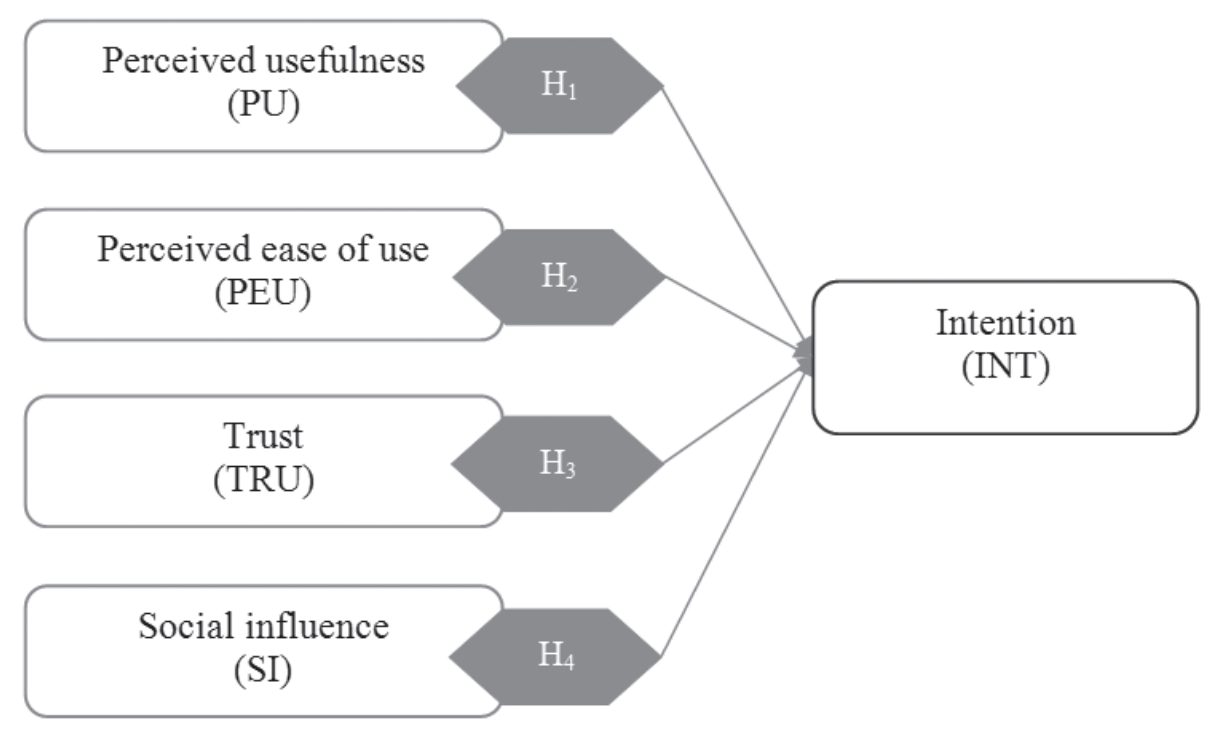

Figure 1: Proposed research model 
Table 1: Variables description in the research model

\begin{tabular}{|c|c|c|c|}
\hline Variable & & Explanation & Source \\
\hline \multirow{4}{*}{$\begin{array}{l}\text { Perceived } \\
\text { usefulness (PU) }\end{array}$} & PU1 & Fintech service can meet the needs of customers. & \multirow{4}{*}{$\begin{array}{l}\text { Kim et al. (2016), Lee } \\
\text { (2017), Wonglimpiyarat } \\
\text { (2017), Ryu (2018). }\end{array}$} \\
\hline & PU2 & Customers save a lot of time when using fintech services. & \\
\hline & PU3 & Using fintech services increases customer work efficiency. & \\
\hline & PU4 & $\begin{array}{l}\text { Customers can access many utilities attached when using } \\
\text { fintech service. }\end{array}$ & \\
\hline \multirow[t]{3}{*}{$\begin{array}{l}\text { Perceived ease of } \\
\text { use (PEU) }\end{array}$} & PEU1 & $\begin{array}{l}\text { The operations performed in fintech service are quite simple } \\
\text { for customers. }\end{array}$ & \multirow{3}{*}{$\begin{array}{l}\text { Riquelme and Rios } \\
\text { (2010), Akturan and } \\
\text { Tezcan (2012), Szopinski } \\
\text { (2016). }\end{array}$} \\
\hline & PEU2 & $\begin{array}{l}\text { Instructions on the fintech service system are clear and easy } \\
\text { to understand. }\end{array}$ & \\
\hline & PEU3 & $\begin{array}{l}\text { Customers can interact with fintech service system } \\
\text { everywhere. }\end{array}$ & \\
\hline \multirow{3}{*}{$\begin{array}{l}\text { Customer trust } \\
\text { (TRU) }\end{array}$} & TRU1 & Fintech service has good information security ability. & \multirow{3}{*}{$\begin{array}{l}\text { Kesharwani and Bisht } \\
\text { (2012), Hanafizadeh } \\
\text { et al. (2014), Hu et al. } \\
\text { (2019). }\end{array}$} \\
\hline & TRU2 & Fintech service is provided by reputable units only. & \\
\hline & TRU3 & Customers feel confident when using fintech services. & \\
\hline \multirow[t]{3}{*}{$\begin{array}{l}\text { Social influence } \\
\text { (SI) }\end{array}$} & SI1 & $\begin{array}{l}\text { Neighbors (such as relatives, friends, colleagues...) often use } \\
\text { fintech services. }\end{array}$ & \multirow{3}{*}{$\begin{array}{l}\text { Kim et al. (2016), Koksal } \\
\text { (2016), Oliveira et al. } \\
\text { (2016). }\end{array}$} \\
\hline & $\mathrm{SI} 2$ & Customer's work/study environment supports fintech services. & \\
\hline & SI3 & Fintech service is in line with the development trend of society. & \\
\hline \multirow{3}{*}{$\begin{array}{l}\text { Itention to use } \\
\text { fintech services } \\
\text { (INT) }\end{array}$} & INT1 & If not used, customers intend to use fintech service soon. & \multirow{3}{*}{$\begin{array}{l}\text { Kim et al. (2016), Oliveira } \\
\text { et al. (2016), Lee (2017), } \\
\text { Wonglimpiyarat (2017), } \\
\text { Ryu (2018), Hu et al. } \\
(2019) .\end{array}$} \\
\hline & INT2 & If using, customers want to continue using fintech services. & \\
\hline & INT3 & $\begin{array}{l}\text { Customers will recommend fintech services to their neighbors } \\
\text { or relatives. }\end{array}$ & \\
\hline
\end{tabular}

Fintech companies have provided customers with more options when accessing financial services, instead of customers only accessing through the traditional banking model as before. Moreover, the services provided by fintech companies are often creative so they will help customers have more interesting and especially optimal experiences. Therefore, fintech has a significant impact on the banking industry. If banks do not update this trend, it will become lagging, not keeping up with global development trends, which will significantly affect the long-term development of the bank. Recognizing this, in March 2017, the State Bank of Vietnam established a Fintech Steering Committee to support the completion of the legal framework and facilitate fintech companies' development. Along with that, many commercial banks are also actively cooperating with fintech companies to take advantage of the available technological advantages of these companies. Indeed, the survey results of Ernst \& Young show that $85 \%$ of banks make the statement that the strategy of converting to digital banking is their most important goal. By cooperating with fintech companies, banks will have a great advantage when they take advantage of new technological innovations optimally, thereby helping the bank to improve service quality, reduce cost, and increase productivity.

In recent years, the cooperation between banks and fintech companies in Vietnam has also increased significantly, such as:

- Military Commercial Joint Stock Bank (MB) has cooperated with the Military Industry and Telecommunications Group (Viettel) to offer modern technology application services. Specifically, in 2010, MB launched the Bank Plus service market with many modern features, Bank Plus has three main service packages: Bank Plus account, Bank Plus card, Mobile Bank Plus. Through Viettel mobile network, MB introduced and connected modern banking services to customers without necessarily expanding infrastructure and human resources. After only one year, MB has more than 45,000 individual customers through this channel.

- In November 2012, the Online Mobile Services Joint Stock Company (M_Service) was licensed by the State Bank of Vietnam to provide MoMo Remittance service, which was coordinated by M_Service in cooperation with Joint Stock Commercial Bank for Foreign Trade Vietnam 
(Vietcombank). In October 2015, the State Bank of Vietnam officially licensed M_Service to provide MoMo E-wallet service.

- In March 2018, Vietnam Joint Stock Commercial Bank for Industry and Trade (VietinBank) signed a cooperation agreement with Opportunity Network Company (ON), which is the leading UK Fintech company. Currently, ON is a partner of UBS, Citizens Bank, Alfa-Bank, London Stock Exchange Group, Intesa Sanpaolo, Caixabank, Eurobank, YPO, Dentons. This partnership enables VietinBank's business customers to connect with over 15,000 businesses in 113 countries. With this cooperation, domestic businesses will have the opportunity to expand the market with foreign partners. Along with that, VietinBank will accompany customers in each connection business, providing financial solutions. Thereby, VietinBank will help customers access to banking services optimally.

- At the end of 2018, Vietnam Prosperity Joint Stock Commercial Bank (VPBank) cooperated with SAP SE Group to equip solutions for digital banking and mobile banking needs. Accordingly, VPBank deployed SAP Omnichannel Banking (OCB) software, along with SAP (PE) advanced support services and SAP application maintenance support (AMS) to improve service quality.

- Besides, International Commercial Joint Stock Bank (VIB) has cooperated with FinTech Weezi to launch MyVIB Keyboard, a social networking application. This application allows customers using MyVIB mobile banking application to transfer money quickly within 5 minutes while chatting on social networks such as Facebook Messenger, Viber, Zalo, Whatsapp, WeChat, Twitter, Snapchat.
- In addition, Vietnam Technological and Commercial Joint Stock Bank (Techcombank) has cooperated with FinTech Fastacash Company to launch F@st Mobile, which is a fast transfer application via Facebook and Google+.

In general, fintech in Vietnam has developed very quickly in recent years. Fintech companies also cooperate with banks to offer innovative products and services applying high technology. Thereby, banks have favorable conditions to improve service quality, increase operational efficiency. Fintech companies also benefit from cooperating to exploit, use data, and network of available customers of the bank. In particular, fintech companies themselves are not financial companies, so currency transactions still have to go through banks. In other words, fintech companies need to work with banks to develop together. For customers, they will have more options when accessing banking services, and they will save a lot of time and increase efficiency when using banking services.

\subsection{Regression Results}

To identify suitable factors to be included in the research model, the authors conducted Cronbach's Alpha test and exploratory factor analysis (EFA). The results of testing Cronbach's Alpha and exploring factor analysis (EFA) are presented in Table 2 as follows:

Table 2 shows that four independent variables can influence the intention to use fintech (INT) services, including perceived usefulness (PU), social influence (SI), trust (TRU), and perceived ease of use (PEU). This is an important basis for the authors to conduct multiple regression analysis to estimate the research model in the next step.

Table 2: Results of the testing research model

\begin{tabular}{|c|c|c|c|c|c|c|}
\hline \multirow{2}{*}{ Variables } & \multirow{2}{*}{ Code } & \multirow{2}{*}{ Cronbach's Alpha } & \multicolumn{4}{|c|}{ Component } \\
\hline & & & 1 & 2 & 3 & 4 \\
\hline \multirow{4}{*}{ Perceived usefulness (PU) } & PU1 & \multirow{4}{*}{0.853} & 0.886 & & & \\
\hline & PU2 & & 0.882 & & & \\
\hline & PU3 & & 0.767 & & & \\
\hline & PU4 & & 0.761 & & & \\
\hline \multirow{3}{*}{ Social influence (SI) } & $\mathrm{SI3}$ & \multirow{3}{*}{0.882} & & 0.897 & & \\
\hline & $\mathrm{SI} 2$ & & & 0.892 & & \\
\hline & SI1 & & & 0.880 & & \\
\hline \multirow{3}{*}{ Trust (TRU) } & TRU1 & \multirow{3}{*}{0.852} & & & 0.894 & \\
\hline & TRU2 & & & & 0.888 & \\
\hline & TRU3 & & & & 0.827 & \\
\hline \multirow{3}{*}{ Perceived ease of use (PEU) } & PEU1 & \multirow{3}{*}{0.781} & & & & 0.861 \\
\hline & PEU3 & & & & & 0.799 \\
\hline & PEU2 & & & & & 0.798 \\
\hline
\end{tabular}


ANOVA test shows that the results of estimating the research model are significant at a $1 \%$ significance level (see Table 3). Moreover, the R Square $=73 \%$, this means that $73 \%$ of the variation in fintech customers' intention to use fintech services will be explained by the independent variables in the model.

So, with a $1 \%$ significance level, the customer's intention to use fintech services is positively affected by four independent variables: Perceived usefulness (PU), social influence (SI), trust (TRU), and perceived ease of use (PEU) (see Figure 2). Based on this basis, the results of estimating the research model have the following equation:

$$
\begin{aligned}
\mathrm{INT}= & 0.528 * \mathrm{PU}+0.359 * \mathrm{SI}+0.304 * \mathrm{TRU}+0.200 \\
& * \mathrm{PEU}
\end{aligned}
$$

\begin{tabular}{|c|c|c|}
\hline \multicolumn{3}{|c|}{ Dependent Variable: Intention (INT) } \\
\hline Variable & Beta & Sig. \\
\hline Perceived usefulness (PU) & $0.528^{\star * \star}$ & 0.000 \\
\hline Social influence (SI) & $0.359^{* * *}$ & 0.000 \\
\hline Trust (TRU) & $0.304^{\star \star *}$ & 0.000 \\
\hline Perceived ease of use (PEU) & $0.200^{\star * \star}$ & 0.000 \\
\hline $\mathrm{N}$ & \multicolumn{2}{|c|}{620} \\
\hline ANOVA (sig.) & \multicolumn{2}{|c|}{$0.000^{* \star *}$} \\
\hline R Square & \multicolumn{2}{|c|}{$73 \%$} \\
\hline
\end{tabular}

Table 3: Results of the coefficient estimation

Note: ${ }^{* * *}$ indicates significance at the $1 \%$ level.
- Impact of perceived usefulness (PU) on the intention to use fintech (INT) services:

The research results show that the perception of usefulness (PU) positively affects the intention to use fintech (INT) services. This result is consistent with the previous judgment of Kim et al. (2016), Lee (2017), and Wonglimpiyarat (2017). This shows that the usefulness of fintech services will contribute significantly to improving the quality of bank services, and will significantly improve the efficiency of users' work. Therefore, customers tend to want to use fintech services with many useful features that are understandable. In Vietnam, fintech services are still quite new. Therefore, usefulness is a matter of great concern to customers before they intend to use fintech services.

\section{- The impact of social influence (SI) on the intention to use fintech (INT) services:}

The authors found the positive impact of social influence (SI) and on the intention to use fintech (INT) services. Accordingly, when customers see neighbors (such as relatives, friends, colleagues) using fintech services, customers will tend to use it. This is very relevant to the reality in Vietnam because people are often very concerned about other people in society, so the influence of society often has a great impact on the intention to use the service of the customer. So, it can be said that social influence is one of the important factors that have a positive impact on the customer's intention to use fintech services. This effect is also found in Kim et al. (2016), Koksal (2016), and Oliveira et al. (2016).

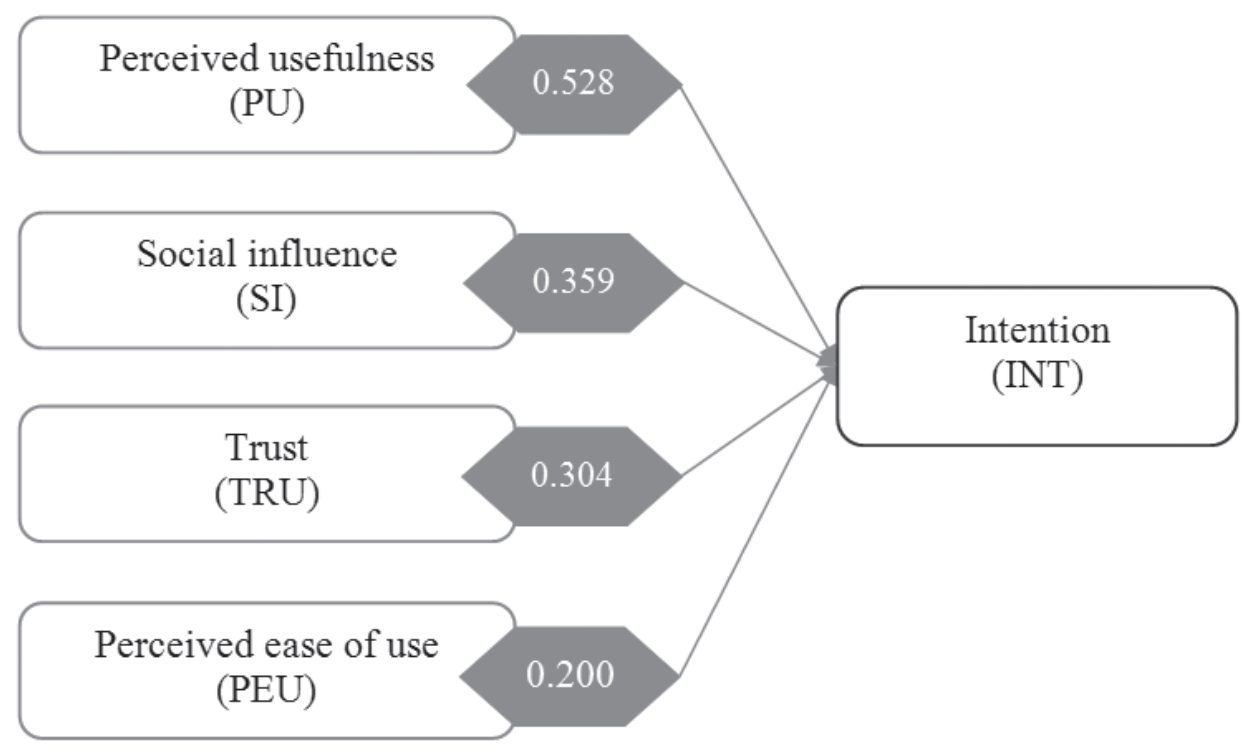

Figure 2: Results of the coefficient estimation 


\section{- The impact of trust (TRU) on the intention to use fintech (INT) services:}

Research results show that customer trust (TRU) positively affects the intention to use fintech (INT) services. This effect is also consistent with previous research results of Kesharwani and Bisht (2012), Hanafizadeh et al. (2014), $\mathrm{Hu}$ et al. (2019). In Vietnam, there are many banks providing fintech services with quite similar features. Therefore, trust is always an important priority for customers who intend to use fintech services. Accordingly, the banks that are frequently traded by customers and the prestigious banks are the places that create the trust of customers, and the customers also tend to give priority to using fintech services of this bank.

\section{- Impact of perceived ease of use (PEU) on the intention to use fintech (INT) services:}

The authors have found the positive impact of the perceived ease of use (PEU) on the intention to use fintech (INT) services. This is also quite consistent with the characteristics of a relatively new service such as fintech. Because, when intending to use a service, customers often ask the question like "Is it easy to use or not?". Accordingly, if the fintech service is comfortable and easy to use, customers will not hesitate when making an intention to use this service. The positive impact of the perceived ease of use on fintech intentions is also consistent with previous observations of Riquelme and Rios (2010), Akturan and Tezcan (2012), Szopinski (2016).

\section{Conclusions}

Research results show that fintech service is very important for the banking sector in Vietnam, a developing country with fintech service which is quite new. Using multivariate regression, this paper has achieved great success by identifying the factors that influence customers' intention to use fintech services. Accordingly, the intention to use fintech (INT) services is positively affected by the perception of usefulness (PU), social impact (SI), customer trust (TRU), and perceived ease of use (PEU). So, to improve customers' intention to use fintech services, banks need to pay attention to elements of the service's characteristics such as usability and ease of use. At the same time, customer trust and social influence are also issues that banks need to be concerned about. These are important policy implications for regulators at banks. Not only that, the results of this study are also valuable for policymakers and researchers.

Based on the results of this study, the authors propose some policy implications to promote the development of fintech services in the banking sector in Vietnam as follows:

- Banks need to further improve the features of fintech services, which focus primarily on improving the usefulness of the service to suit all customer segments. At the same time, the transaction process through fintech services should be designed easily and conveniently for customers.

- Banks need to have a strategy to enhance the image and reputation of banks in the market. At the same time, banks also need to actively promote and disseminate knowledge about products and services to the community to expand market share and limit risks in transactions.

- Banks need to strengthen their cooperation with fintech to take advantage of the companies' existing technological advantages, thereby aiming to improve the quality of hightech application services and bring the better experiences to the customers. With this cooperation, banks can diversify products and services applying high technology, improving access to customers at low cost. At the same time, the banks themselves should increase investment, upgrade technology infrastructure, and enhance system security.

- Banks need to strengthen the training of high-quality human resources. This human resource is not only good at specialized knowledge but also must have an understanding of applications based on modern technology in financial services.

- Also, the authorities need to supplement and complete the legal framework, mechanism, and policies for fintech activities. At the same time, building fintech development policies must be linked to monetary and economic policies.

Although the research goal has been achieved, the research is still limited without considering several of other factors that may influence the fintech customer service, such as information technology platform, financial capacity of customers, risks when using the service. On the other hand, fintech services are quite new to Vietnam, so the authors have not been able to collect. This is a major limitation of this research.

\section{References}

Abbad, M. M. (2013). E-Banking in Jordan. Behaviour \& Information Technology, 32(7), 681-694. https://doi.org/10.10 80/0144929X.2011.586725

Abrahão, R. D. S., Moriguchi, S. N., \& Andrade, D. F. (2016). Intention of adoption of mobile payment: an analysis in the light of the unified theory of acceptance and use of technology (UTAUT). RAI Revista de Administração e Inovação, 13(3), 221-230. https://doi.org/10.1016/j.rai.2016.06.003

Akturan, U., \& Tezcan, N. (2012). Mobile Banking Adoption of the Youth Market. Marketing Intelligence \& Planning, 30(4), 444-459. https://doi.org/10.1108/02634501211231928

Berger, A. N. (2003). The economic effects of technological progress: evidence from the banking industry. Journal of Money, Credit and Banking, 35(2), 141-176.

Arner, D. W., Barberis, J. N., \& Buckley, R. P. (2015). The Evolution of Fintech: A New Post-Crisis Paradigm?. University of Hong 
Kong Faculty of Law Research Paper No. 2015/047, UNSW Law Research Paper No. 2016-62. Available at SSRN: http:// dx.doi.org/10.2139/ssrn.2676553

Chau, V. S., \& Ngai, L. W. L. C. (2010). The Youth Market for Internet Banking Services: Perceptions, Attitude and Behaviour. Journal of Services Marketing, 24(1), 42-60.

Chen, M. A., Wu, Q., \& Yang, B., (2019). How valuable is fintech innovation?. Review of Financial Studies, 32(5), 2062-2106.

Devadevan, V. (2013). Mobile banking in India-issues \& challenges. International Journal of Emerging Technology and Advanced Engineering, 3, 516-520.

Fuster, A., Plosser, M., Schnabl, P., \& Vickery, J. (2019). The role of technology in mortgage lending. The Review of Financial Studies, 32(5), 1854-1899. https://doi.org/10.1093/rfs/hhz018

Gomber, P., Koch, J. A., \& Siering, M. (2017). Digital Finance and FinTech: Current research and future research directions. Journal of Business Economics, 87(5), 537-580. https://doi. org/10.1007/s11573-017-0852-x

Hu, Z., Ding, Z., Li, S., Chen, L., \& Yang, S. (2019). Adoption Intention of Fintech Services for Bank Users: An Empirical Examination with an Extended Technology Acceptance Model. Symmetry, 11(3), 1-16. https://doi.org/10.3390/sym11030340

Hanafizadeh, P., Behboudi, M., Koshksaray, A. A., \& Tabar, M. J. S. (2014). Mobile-Banking Adoption by Iranian Bank Clients. Telematics and Informatics, 31(1), 62-78. https://doi. org/10.1016/j.tele.2012.11.001

Isaac, O., Abdullah, Z., Aldholay, A. H., \& Ameen, A. A. (2019). Antecedents and outcomes of internet usage within organizations in Yemen: An extension of the Unified Theory of Acceptance and Use of Technology (UTAUT) model. Asia Pacific Management Review, 12(4), 335-354. https://doi. org/10.1016/j.apmrv.2018.12.003

Kesharwani, A., \& Bisht, S. S. (2012). The Impact of Trust and Perceived Risk on Internet Banking Adoption in India. International Journal of Bank Marketing, 30, 303-322. https:// doi.org/10.1108/02652321211236923

Kim, Y., Choi, J., Park, Y., \& Yeon, J. (2016). The adoption of mobile payment services for "Fintech". International Journal of Applied Engineering Research, 11(2), 1058-1061.

Kissi, P. S., Oluwatobiloba, M. K., \& Berko, A. Y. (2017). Factors affecting university students Intentions to use debit card services: An empirical study based on UTAUT. Business, Management and Education, 15(2), 196-210. https://doi. org/10.3846/bme.2017.378

Koksal, M. H. (2016). The Intentions of Lebanese Consumers to Adopt Mobile Banking. International Journal of Bank Marketing, 34(3), 327-346. https://doi.org/10.1108/IJBM-032015-0025

Lee, S. (2017). Evaluation of mobile application in user's perspective: Case of P2P lending apps in fintech industry. KSII Transactions on Internet \& Information Systems, 11(2), 1105-1117. https://doi.org/10.3837/tiis.2017.02.027

Milian, E. Z., Spinola, M. D. M., \& Carvalho, M. M. D. (2019). Fintechs: A literature review and research agenda. Electronic
Commerce Research and Applications, 34, 1-21. https://doi. org/10.1016/j.elerap.2019.100833

Nakashima, T. (2018). Creating Credit by Making Use of Mobility with Fintech and IoT. IATSS Research, 42(2), 61-66. https://doi. org/10.1016/j.iatssr.2018.06.001

Nguyen, T. O. (2020). Factors Affecting the Intention to Use Digital Banking in Vietnam. Journal of Asian Finance, Economics and Business, 7(3), 303-310. https://doi.org/10.13106/jafeb.2020. vol7.no3.303

Nguyen, D. D., Dinh, H. C., Nguyen, D. V. (2020). Promotion of Fintech Application for the Modernization of Banking-Finance System in Vietnam. Journal of Asian Finance, Economics and Business, 7(6), 127-131. https://doi.org/10.13106/jafeb.2020. vol7.no6.127

Oliveira, T., Thomas, M., Baptista, G., \& Campos, F. (2016). Mobile payment: understanding the determinants of customer adoption and intention to recommend the technology. Computers in Human Behavior, 61, 404-414. https://doi.org/10.1016/j. chb.2016.03.030

Phan, D. T. T., Nguyen, T. T. H., \& Bui, T. A. (2019). Going beyond Border? Intention to Use International Bank Cards in Vietnam. Journal of Asian Finance, Economics and Business, 6(3), 315-325. https://doi.org/10.13106/jafeb.2019.vol6.no3.315

Philippon, T. (2015). Has the finance industry become less efficient? On the theory and measurement of financial intermediation. The American Economic Review, 105(4), 1408-1438.

Riquelme, H. E., \& Rios, R. E. (2010). The Moderating Effect of Gender in the Adoption of Mobile Banking. The International Journal of Bank Marketing, 28, 328-341. http://dx.doi. org/10.1108/02652321011064872

Ryu, H. S. (2018). What Makes Users Willing or Hesitant to Use Fintech?: The Moderating Effect of User Type. Industrial Management \& Data Systems, 118(3), 541-569. https://doi. org/10.1108/IMDS-07-2017-0325

Salmony, M. (2014). Access to accounts: why banks should embrace an open future. Journal of Payments Strategy \& Systems, 8(2), 169-170.

Szopinski, T. S. (2016). Factors Affecting the Adoption of Online Banking in Poland. Journal of Business Research, 69(11), 4763-4768. http:// dx.doi.org/10.1016/j.jbusres.2016.04.027

Thakor, A. V. (2020). Fintech and banking: What do we know? Journal of Financial Intermediation, 41, 1-13. https://doi. org/10.1016/j.jfi.2019.100833

Tran, T. A., Han, K. S., \& Yun, S. Y. (2018). Factors influencing the intention to use mobile payment service using fintech systems: Focused on Vietnam. Asia Life Sciences, 15(3), 1731-1747.

Venkatesh, V., Morris, M. G., Davis, G. B., \& Davis, F. D. (2003). User acceptance of information technology: Toward a unified view. MIS Quarterly: Management Information Systems, 27(3), 425-478. https://doi.org/10.2307/30036540

Wonglimpiyarat, J. (2017). Fintech banking industry: a systemic approach. Foresight, 19(6), 590-603. https://doi.org/10.1108/ FS-07-2017-0026 